\title{
Wykorzystanie nowoczesnych technologii w rolnictwie precyzyjnym
}

http://dx.doi.org/10.18778/8142-085-3.09

\author{
Robert Różycki, Karol Żmich \\ Katedra Zarządzania Produkcją i Logistyki, Wydział Inżynierii Zarządzania \\ Politechnika Poznańska
}

\section{Wstęp}

Rolnictwo jest jednym z podstawowych i najstarszych działów gospodarczej działalności człowieka. Jego głównym zadaniem jest dostarczenie produktów żywnościowych w wyniku celowej uprawy roślin i hodowli zwierząt. Oprócz wytwarzania żywności, rolnictwo dostarcza też wielu surowców dla przemysłu, kształtuje środowisko przyrodnicze i krajobraz, tworzy miejsca pracy. Przez tysiąclecia ulegało przemianom i przewartościowaniom, dzięki czemu dzisiaj nadal jest podstawowym filarem gospodarek państw. Rolnictwo należy do sektorów gospodarki o największym wpływie na środowisko naturalne i zdrowie, w tym także przynoszącym działania szkodliwe. Dlatego odpowiednie przystosowanie narzędzi i technologii umożliwia efektywne wykorzystywanie natury w sposób niebędący dla niej zagrożeniem.

Celem pracy jest przedstawienie współczesnego rolnictwa, które jest ukierunkowane na zwiększanie produktywności oraz minimalizowanie kosztów. Zaprezentowane zostaną przykłady systemów wspomagania rolnictwa precyzyjnego.

\section{Rewolucja 4.0}

Świat, a w szczególności wytwórczość ludzka, stoi na krawędzi zastoju technologicznego. Dotyczy to każdej dziedziny, w której produkowane są przedmioty użytkowe. Można to zjawisko określić słowami Klausa Schwaba, założyciela i przewodniczącego World Economic Forum: „Stoimy u progu technologicznej rewolucji, która gruntownie zmienia sposób, w jaki żyjemy, pracujemy i współ- 
istniejemy. W swojej skali, zakresie i kompleksowości transformacja ta będzie czymś, czego ludzkość dotychczas nie doświadczyła [...]”.

Przedsiębiorstwa korzystają z tzw. wskaźników KPI (ang. Key Perfomance Indicators) i dzięki nim analizują swoją produkcję, zyski i wiele innych aspektów funkcjonowania. Obecnie nie jest możliwe zwiększenie poszczególnych wskaźników (produktywność, zmniejszenie kosztów, zmniejszenie przestojów) o 10$15 \%$, albo i więcej, ponieważ konkurencja dysponuje tymi samymi technologiami i rynkami zbytu. Dlatego wypatruje się nowego sposobu wyprzedzenia konkurencji. Pomocne mogą stać się tutaj nowe technologie.

Termin Rewolucja 4.0 pochodzi z projektu strategii technik wysokich, promującego komputeryzację procesów wytwórczych, a opracowywanego przez rząd niemiecki. Po raz pierwszy użyto tego terminu na targach w Hanowerze w 2011 roku ${ }^{1}$. W październiku 2012 r. grupa robocza kierowana przez Siegfrieda Daisa z firmy Robert Bosch $\mathrm{GmbH}$ przedstawiła rządowi federalnemu zestaw zaleceń wdrożeniowych koncepcji, a 8 kwietnia 2013 r. grupa ta zaprezentowała raport końcowy, który opisywał, w jaki sposób wprowadzenie założeń koncepcji pomoże w rozwoju gospodarki².

Definicyjnie Rewolucja 4.0 jest wspólnym terminem dla technik i zasad funkcjonowania organizacji, które wspólnie stosują lub używają systemów cyber-fizycznych, Internetu rzeczy i przetwarzania chmurowego. Według takiego podejścia jest ona urzeczywistnieniem inteligentnej produkcji, w której systemy cyber-fizyczne sterują procesami fizycznymi, tworzą wirtualne (cyfrowe) kopie świata realnego i podejmują zdecentralizowane decyzje, a poprzez Internet rzeczy w czasie rzeczywistym komunikują się i współpracują ze sobą oraz z ludźmi, natomiast dzięki przetwarzaniu chmurowemu są oferowane i użytkowane usługi wewnętrzne i międzyoperacyjne ${ }^{3}$.

Rewolucja przemysłowa według Encyklopedii PWN to określenie całości zmian technicznych, ekonomicznych i społecznych będących konsekwencją transformacji gospodarki opartej na wykorzystaniu biologicznych, odnawialnych źródeł energii (mięśnie, woda, wiatr, drewno), do gospodarki opartej na mineralnych źródłach energii (węgiel - XVIII-XIX w., ropa naftowa - XX w.) ${ }^{4}$, jest rezultatem zastosowania nowych, udoskonalonych narzędzi pracy we wszystkich gałęziach przemysłu.

Pierwsza rewolucja przemysłowa (koniec XVIII w. - pierwsza połowa XIX w.) dotyczyła przejścia z produkcji manufakturowej i rzemieślniczej do zmechanizowanej produkcji fabrycznej (wykorzystywanie szeregu wynalazków technicznych). Największe znaczenie miało wynalezienie maszyny parowej, zastosowanej w górnictwie i przemyśle włókienniczym. Przełomowe okazało się też w hutnictwie zastąpienie węgla drzewnego koksem.

1 http://www.vdi-nachrichten.com/Technik-Gesellschaft/Industrie-40-Mit-Internet-DingeWeg-4-industriellen-Revolution [dostęp 20.04.2017].

2 http://www.plattform-i40.de/I40/Navigation/DE/Home/home.html [dostęp 20.04.2017].

3 http://www.snom.mb.tu-dortmund.de/cms/de/forschung/Arbeitsberichte/DesignPrinciples-for-Industrie-4_0-Scenarios.pdf [dostęp 20.04.2017].

4 http://encyklopedia.pwn.pl/haslo/rewolucja-przemyslowa;3967502.html [dostęp 20.04.2017]. 
W drugiej rewolucji przemysłowej (lata 70. XIX stulecia) największymi innowacjami, które wówczas zrewolucjonizowały i zdynamizowały przemysł, były dwa nowe źródła energii: elektryczność i silnik spalinowy. Rozpoczęła się era produkcji masowej, z zastosowaniem podziału pracy.

Trzecią rewolucję przemysłową (lata 60. ub. stulecia) wyzwoliły przemysłowe aplikacje sterowników programowalnych, otwierające erę automatyzacji przemysłu opartej na zaawansowanej elektronice i informatyce. Trzecia rewolucja przemysłowa określana jest mianem naukowo-technicznej.

Czwarta rewolucja przemysłowa to czasy obecne. Jest ona wywołana m.in. przez:

- bazowanie w procesach decyzyjnych na symulacjach i przetwarzaniu danych w czasie rzeczywistym,

- połączenie maszyna-maszyna i maszyna-człowiek,

- wprowadzanie cyfryzacji w każdym aspekcie produkcji,

- nowe technologie wytwórcze.

Poniższa grafika przedstawia wszystkie rewolucje przemysłowe na osi czasu. Widać na niej, że wzmaga się intensywność powstawania nowych technologii $\mathrm{i}$ ich wykorzystywania w procesach produkcyjnych. W ostatnich latach obserwuje się nasilenie zgłaszania patentów oraz ich wykorzystania w celu opracowania nowych technologii.

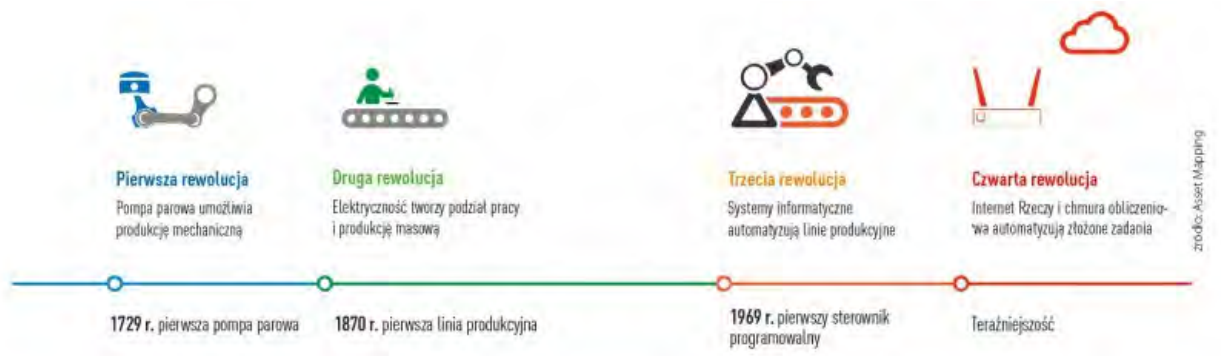

Rysunek 1. Cztery rewolucje przemysłowe

Źródło: http://www.magazynprzemyslowy.pl/img/165/4rewolucjeprzemyslowe8028ec4c3fede7d341c04132037928b3.jpg [dostęp 20.04.2017]

Filarami czwartej rewolucji przemysłowej są:

- Internet rzeczy (IoT, ang. Internet of Things) - pozwala na globalny dostęp do maszyn i baz danych;

- inteligencja maszynowa - zakłada pełną automatyzację procesów produkcyjnych (włączając zmiany organizacyjne w zależności od warunków zewnętrznych $)^{5}$.

5 http://www.astor.com.pl/images/Industry_4-0_Przemysl_4-0/ASTOR_przemysl4_whitepaper. pdf [dostęp 20.04.2017]. 
Internet rzeczy stanowi dynamiczną globalną sieć fizycznych obiektów, systemów, platform i aplikacji, które są zdolne do komunikowania oraz dzielenia się inteligencją pomiędzy sobą, zewnętrznym otoczeniem i ludźmi. Pozwala to wchodzić w interaktywność takich urządzeń jak sensory czy tagi RFID. Ważną częścią IoT są systemy cyber-fizyczne - CPS (ang. Cyber-Physical Systems), czyli takie, które dzięki odczytom z urządzeń mogą przetwarzać ogromne ilości danych. W przeciwieństwie do tzw. wbudowanych systemów (posiadających hardware i software dla danego obiektu) są one „otwarte”, pracują na wirtualnym podłożu, zbudowanym $\mathrm{z}$ wielu różnorodnych elementów współpracujących ze sobą. Należy również wspomnieć o Internecie usług (IoS, ang. Internet of Services), gdzie Internet reprezentują usługi i ich funkcjonalności, jako komponenty sytemu. Przykładem może być dostarczanie części, przedmiotów w zależności od położenia modułu montującego czy wykorzystującego dostarczane części ${ }^{6}$.

Aby Internet rzeczy zaistniał, muszą być spełnione trzy warunki (Kokot, Kolenda, 2015):

- Niezbędne jest urządzenie, które zbiera informacje z jakiegoś otoczenia bądź systemu, tzw. sensor. Zbiera on informacje i następnie przekazuje dalej. Można rozróżnić sensory, które zbierają dane automatycznie i przesyłają w czasie rzeczywistym, oraz sensory, których działanie wywołuje użytkownik albo czynnik zewnętrzny (np. ruch);

- Kolejnym urządzeniem jest tzw. odbiornik, który jest w stanie odebrać zebrane informacje, przetworzyć je oraz wykonać żądaną akcję. Przykładem może być komputer, smartfon, który wyświetla wyniki, ale także przedmiot (np. samoregulujące się żaluzje, które w zależności od ilości światła z zewnątrz ustawiają się pod odpowiednim kątem);

- Ostatnim elementem systemu jest część łącząca poprzednie dwa - środek komunikacji - która pozwala przesyłać zebrane dane z sensora do odbiornika, aby ten je przetworzył. Przykładem może być światłowód, Wi-fi, Bluetooth.

Rewolucja przemysłowa 4.0 nie musi się ograniczać do fabryk i przemysłu. Wykorzystanie Internetu rzeczy może pozytywnie wpływać na inne obszary gospodarki. Współczesne rolnictwo wykorzystuje nowoczesne technologie, aby zwiększyć produktywność oraz zminimalizować koszty. Rolnictwo precyzyjne pokazuje, w jaki sposób wykorzystywać dostępną technologię oraz połączenie maszyny z człowiekiem, aby odnosić sukcesy w produkcji.

6 http://www.controlengineering.pl/menu-gorne/artykul/article/czwarta-rewolucja-przemyslowai-przemysl-40-co-oznaczaja-te-pojecia/part/1/ [dostęp 20.04.2017]. 


\section{Rolnictwo - zarys historyczny}

Rolnictwo jest nieodłącznym elementem cywilizacji. Według Encyklopedii PWN jest to „jedna $\mathrm{z}$ najstarszych i podstawowych dziedzin gospodarki, której głównym celem jest dostarczenie człowiekowi żywności do bezpośredniej konsumpcji lub po przetworzeniu w zakładach przemysłu spożywczego, ponadto produkowanie surowców przemysłowych (np. włókna roślinnego i zwierzęcego, skór surowych, używek) w celu zaspokojenia innych (nieżywnościowych) potrzeb człowieka"7.

Rolnictwo jest zawsze uzależnione od środowiska, w jakim jest eksploatowana natura. Człowiek na przestrzeni wieków doskonalił narzędzia i techniki, aby zwiększyć produktywność przyrody. Formy i struktury gospodarstw oraz ich organizacja były i są determinowane zarówno dostępnością podstawowych zasobów produkcyjnych: ziemi, maszyn i kapitału, jak i czynnikami społeczno-politycznymi oraz kulturowymi. Zarówno w przeszłości, jak i obecnie systemy ekonomiczne w rolnictwie cechowała wielka różnorodność, w zależności od regionu świata. Biorąc pod uwagę rewolucje przemysłowe, jakie na przestrzeni wieków regulowały osiągnięcia gospodarki, można wysunąć stwierdzenie, że rolnictwo zawsze było uzależnione od przemysłu ciężkiego.

Początki rolnictwa w Polsce to okres przed naszą erą. Wykopaliska archeologiczne potwierdzają, że już w IV p.n.e. na ziemiach dolnośląskich i małopolskich istniały gospodarstwa rolne. Przejście z epoki brązu w epokę żelaza zdefiniowało na nowo narzędzia rolnicze. W tamtym okresie wykorzystywano płodozmian (uprawa-ugór).

W okresie feudalnym przyrost liczby ludności spowodował konieczność zwiększenia produkcji rolnej. Zaopatrywanie grodów i zamków było nieosiągalne dla zwykłej uprawy, dlatego wprowadzono trójpolówkę (w X w., ale upowszechniła się dopiero w wieku XII). Własność feudalna obejmowała kilka wsi, z których każda specjalizowała się w konkretnej hodowli czy uprawie, aby różnicować produkty.

Gospodarka folwarczno-pańszczyźniana na ziemiach polskich miała silne korzenie. Poddani, którzy pracowali dla swojego suwerena, otrzymywali małą część wytworzonych dóbr na utrzymanie siebie i rodziny. Zaopatrywanie dworu, dziesięcina, pańszczyzna, która nie miała jasno określonej formy $(3,4,5$ dni w tygodniu), daniny były dla ówczesnego rolnika niedogodnościami, które uniemożliwiały rozwój gospodarstw. Zwiększający się popyt na żywność spowodował, że najczęściej uprawiane były zboża: żyto i owies. Polska do tej pory jest eksporterem zboża.

Wiek XIX to postęp techniczny, wzrost nawożenia, melioracje i mechanizacja rolnictwa. Spowodowało to 2-3-krotny wzrost produktywności użytków rolnych w stosunku do poprzedniego stulecia. Na pierwszą połowę XIX w. przypadają na-

7 http://encyklopedia.pwn.pl/haslo/rolnictwo;3968575.html [dostęp 20.04.2017]. 
rodziny przemysłu maszyn i urządzeń rolniczych na ziemiach polskich. W rozwoju rolnictwa bardzo ważna była nauka i szkolnictwo specjalistyczne. Publikowano coraz więcej książek i prac naukowych poświęconych zagadnieniom rolniczym. $\mathrm{Na}$ ziemiach polskich pod zaborami rolnictwo było bardzo zróżnicowane. Spowodowała to odmienna polityka państw zaborczych wobec rolnictwa. W zaborze austriackim państwo ingerowało w gospodarstwa, aby te były opodatkowane. $\mathrm{W}$ zaborze pruskim wyciągano jak najwięcej z ziem uprawnych, a w zaborze rosyjskim tworzyły się ruchy narodowowyzwoleńcze mające w tle reformy i zniesienie pańszczyzny chłopów.

Długi okres zaborów spowodował zróżnicowanie przestrzenne rolnictwa w Polsce, ale to wojna zniszczyła ogromne obszary uprawne. Po niej trzeba było wszystko odbudowywać, w tym również gospodarstwa wiejskie. We wschodniej i środkowej Polsce ziemie uzyskali robotnicy rolni i właściciele małych gospodarstw. Na zachodzie kraju utworzono przede wszystkim gospodarstwa nowe, które otrzymali dawni robotnicy rolni lub ludność przesiedlona z innych części kraju8.

Współcześnie rolnictwo w Polsce próbuje dorównać temu w Europie Zachodniej. Duża liczba małych gospodarstw towarzyszy niezamożnej części ludności, która stanowi znaczny odsetek w Polsce - jest to pozostałość po socjalizmie. Strukturę wielkości i liczebności gospodarstw przedstawia tabela 1, opracowana na podstawie raportu GUS ISSN 2353-5180.

Tabela 1. Przeciętna powierzchnia użytków rolnych ogółem w gospodarstwach rolnych w latach 2013-2015

\begin{tabular}{|c|c|c|c|c|c|c|c|c|c|}
\hline \multirow{2}{*}{ Lata } & \multicolumn{8}{|c|}{ Grupy obszarowe użytków rolnych ogółem w ha } \\
\cline { 2 - 10 } & $\begin{array}{c}\text { Powy- } \\
\text { żej } \\
\text { 1 ha }\end{array}$ & $\mathbf{1 - 2}$ & $\mathbf{2 - 3}$ & $\mathbf{3 - 5}$ & $\mathbf{5 - 7}$ & $\mathbf{7 - 1 0}$ & $\mathbf{1 0 - 1 5}$ & $\mathbf{1 5 - 2 0}$ & $\mathbf{2 0 - 3 0}$ \\
\hline 2013 & 10,45 & 1,46 & 2,42 & 3,88 & 5,88 & 8,32 & 12,10 & 17,20 & 24,13 \\
\hline 2014 & 10,33 & 1,47 & 2,40 & 3,80 & 5,82 & 8,29 & 12,02 & 17,13 & 24,06 \\
\hline 2015 & 10,51 & 1,49 & 2,42 & 3,82 & 5,83 & 8,29 & 12,02 & 17,12 & 24,05 \\
\hline & \multicolumn{7}{|c|}{ Grupy obszarowe użytków rolnych ogółem w ha } \\
\cline { 2 - 11 } & $\mathbf{3 0 - 5 0}$ & $\mathbf{5 0 - 1 0 0}$ & $\mathbf{1 0 0 - 2 0 0}$ & $\mathbf{2 0 0 - 3 0 0}$ & $\mathbf{3 0 0 - 5 0 0}$ & $\mathbf{5 0 0 - 1 0 0 0}$ & $\mathbf{1 0 0 0}$ i więcej \\
\hline 2013 & 37,92 & 67,69 & 135,34 & 243,80 & 385,16 & 681,93 & 2080,59 \\
\hline 2014 & 37,62 & 67,72 & 133,73 & 243,81 & 384,74 & 681,45 & 2069,56 \\
\hline 2015 & 37,66 & 67,95 & 134,18 & 243,89 & 383,82 & 678,08 & 2001,27 \\
\hline
\end{tabular}

Źródło: www.stat.gov.pl [dostęp 20.04.2017].

8 https://www.igipz.pan.pl/tl_files/igipz/ZGWiRL/ARP/03.Rozwoj\%20gospodarki\%20rolnej\%20 w\%20Polsce.pdf [dostęp 20.04.2017]. 
Uważa się, że rolnictwo w naszym kraju zmierza w dobrym kierunku. Polska staje się silna, a dzięki wykorzystaniu nowych technologii może stać się potentatem w wytwarzaniu produktów rolnych.

\section{Rolnictwo precyzyjne}

Logistyka w rolnictwie przede wszystkim zajmuje się ograniczeniem kosztów i czasu potrzebnego na zabiegi agrotechniczne oraz dążeniem do osiągania wyższego plonu. Era bezprzewodowego przesyłania danych otworzyła nowe możliwości rozwiązywania poszczególnych problemów, które w ujęciu logistycznym generowały koszt. Znalezienie sposobu na wyeliminowanie utrudnień równa się optymalizacji kosztowej i czasowej.

Logistyka z założenia eliminuje pracę niepotrzebną. Najszybciej w procesach agrotechnicznych znalazł zastosowanie system GPS. Przy przejazdach ciągnikiem jeden obok drugiego nie da się uniknąć „zakładek”. Najprostszym sposobem usunięcia tego problemu jest dołączenie do maszyny znacznika, który wyznacza następny przejazd ciągnika. Niestety, zastosowanie takiej metody nie jest możliwe w każdej maszynie. Z pomocą przychodzi Global Positioning System. Po zamontowaniu odpowiedniego odbiornika na ciągniku, zintegrowanego z komputerem pokładowym i wyświetlaczem zamontowanym w kabinie, można korzystać z pozycjonowania maszyny. System GPS daje dokładność na poziomie \pm 5 metrów. W wielu dziedzinach taka dokładność jest wystarczająca, lecz nie ma zastosowania w rolnictwie. Na przykładzie firmy John Deere można zobaczyć zastosowanie systemu GPS w rolnictwie precyzyjnym ${ }^{9}$.

Firma posiada trzy sygnały korekcyjne, oferujące różne poziomy dokładności pracy. Sygnał SF1 pozwala prowadzić maszynę z dokładnością $\pm 15 \mathrm{~cm}$. Praca operatora polega na przyjechaniu ciągnikiem na pole, wyznaczeniu pierwszego przejazdu i podążaniu za wskazówkami, które są wyświetlane na ekranie monitora (system kierowania Parallel Tracking) bądź też, po zainstalowaniu odpowiednich urządzeń, można przekazać kierownicę autopilotowi, który będzie podążał wyznaczoną trasą (system kierowania Universal AutoTrack). Sygnał jest darmowy dla wszystkich użytkowników. Dla większej precyzji można wykupić abonament na sygnał SF3, umożliwiający pracę z maszyną z dokładnością $\pm 3 \mathrm{~cm}$. SF3 pozwala dodatkowo na zapamiętanie przejazdów ciągnika do 9 miesięcy, a to z kolei na szybszy powrót do przerwanej pracy, np. ze względu na warunki atmosferyczne.

9 http://www.ppr.pl/technika/maszyny/gps-w-rolnictwie-reflekcje-o-przyszlosci-rolnictwaprecyzyjnego-135653 [dostęp 20.04.2017]. 
Po zamontowaniu w pobliżu pola stacji bazowej dla trzeciego sygnału RTK, która służy za punkt odniesienia, można pracować $\mathrm{z}$ dokładnością $\pm 2,5 \mathrm{~cm}^{10}$. Zaletą tego systemu jest również fakt, że wyznaczanie granic pola odbywa się tylko raz. Dane przetrzymywane są w chmurze. Operator musi tylko dojechać na pole i wcisnąć przycisk, a ciągnik sam zacznie pracować. Traktorzysta mniej się męczy i skupia tylko na kontrolowaniu pracy maszyny i toru jazdy ciągnika. Mniejsze zmęczenie operatora przekłada się na dłuższą, wydajniejszą pracę, a co za tym idzie, lepsze wyniki we wskaźnikach. Trzeba również powiedzieć, że do odbierania wszystkich trzech sygnałów służy jeden odbiornik StarFire 6000. Jest to szczególnie ważne, ponieważ rozwój przedsiębiorstwa (w tym przypadku zmiana sygnału na dokładniejszy) nie wiąże się z dodatkowymi kosztami. System prowadzenia używany jest w ciągnikach, opryskiwaczach samojezdnych, sieczkarniach i kombajnach.

Zwiększenie wydajności dokonuje się przede wszystkim poprzez właściwą gospodarkę danymi. Pola nie są takie same w każdym miejscu, szczególnie gdy mówimy o dużych polach. Często granice upraw różnią się od granic dziełek na mapach ewidencyjnych, co utrudnia obliczenie powierzchni upraw w momencie, kiedy trzeba starać się o dopłaty. Dzięki systemowi można wyznaczyć granice w domu, na podstawie zdjęć satelitarnych. Co więcej, wirtualne granice naniesione w domu będą widoczne dla maszyn, co skraca czas wyznaczania przejazdów. Rolnictwo precyzyjne, czyli dokładność stosowania odpowiednich dawek nawozów w odpowiednich miejscach, obniża koszty i przyczynia się do większego zysku. Najczęściej zbieranie informacji o areale uprawowym i zasobności gleby w składniki mineralne zleca się firmie zewnętrznej (Dominik, 2010). Pole dzieli się na poszczególne sekcje, następnie kierowca, odczytując swoją pozycję z systemu GPS, sondą (zamontowaną najczęściej na quadzie) zbiera próbki, które poddaje się badaniom. $\mathrm{Z}$ wyników można odczytać poziom $\mathrm{pH}$ gleby, zawartość azotu, potasu, ukształtowanie terenu (podczas pobierania próbki czujnik umieszczony na quadzie zapisuje jego pozycję w trzech płaszczyznach) itd. Przykład przeprowadzonego badania przedstawia rysunek 2 .

Oprócz tego podczas zbiorów zapisywane są w kombajnie dane na temat wielkości plonu i wilgotności ziarna. Wszystkie informacje łączy się, by stworzyć mapy pól. Powstaje przejrzysty przekaz mówiący o tym, gdzie trzeba zastosować więcej nawozów, gdzie konieczne będzie użycie wapna itp. Aby w czasie rzeczywistym manipulować dawkami, konieczne jest użycie komputera nie tylko w ciągniku, ale również w narzędziu.

Po stworzeniu map są one przesyłane do komputera w ciągniku, który łączy się z maszyną za pomocą ISOBUS ${ }^{11}$. Jest to pewien rodzaj standaryzacji umożliwiający korzystanie z maszyny poprzez wyświetlacz w kabinie ciągnika, jeden do każdej

10 http://www.deere.pl/pl_PL/docs/html/brochures/publication.html?id=6e78fbad\#46 [dostęp 20.04.2017].

11 https://www.agrofakt.pl/magistrala-isobus/ [dostęp 19.04.2017]. 
maszyny. Maszynę łączy się z ciągnikiem za pomocą wtyczki działającej podobnie do USB. Złącze jest takie samo dla każdego urządzenia, co nie wiąże się z kosztami przystosowania nowej maszyny do ciągnika. W momencie, kiedy np. rozsiewacz odczyta dane z mapy, automatycznie steruje dawką stosownie do potrzeb. Zapobiega to przedawkowaniu nawozu (odchodzi koszt związany z nadmiernym zużyciem nawozu) czy podaniu zbyt małych dawek (plon byłby niższy w stosunku do oczekiwanego, co przełożyłoby się na niższy zysk). Dodatkowo w momencie, gdy nawóz podawany jest w okresie wegetacji roślin, komputer wspomaga się odczytem, w czasie rzeczywistym - z sensorów badających gęstość uprawy bądź poziom chlorofilu w roślinach, zamontowanych najczęściej na przednim tuzie ciągnika. W przypadku pracy z opryskiwaczem pozycjonowanie pozwala na wyłączanie sekcji opryskiwacza w przypadku tzw. zakładek na klinach. Wszystko to sprowadza się do ograniczenia nadmiernego zużycia środków ochrony roślin, co pozwala zaoszczędzić wydatki (Barwick, Romaniuk, 2012: 15-24).

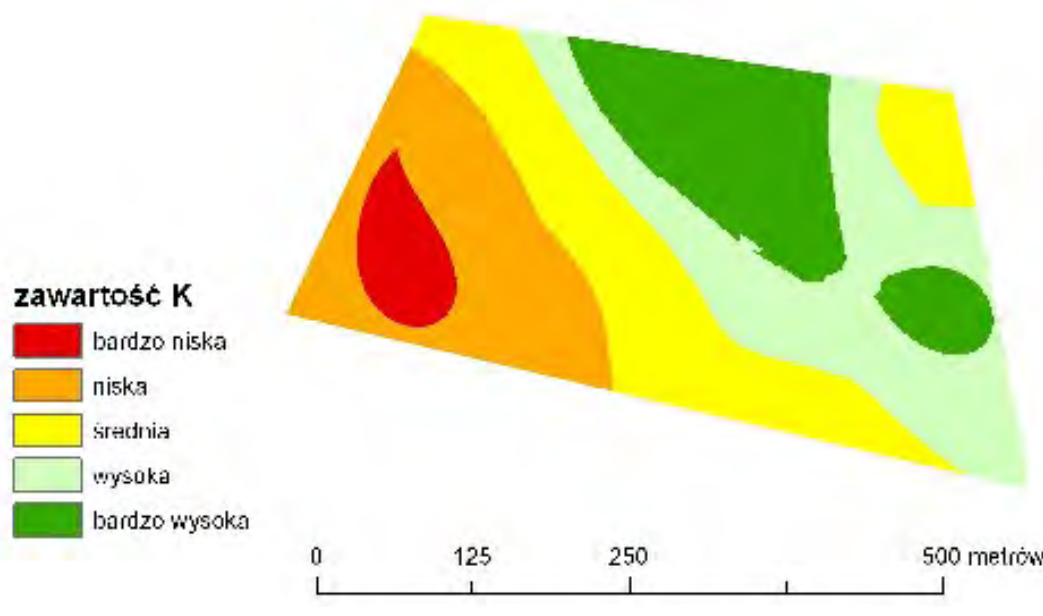

Rysunek 2. Stężenie potasu w poszczególnych miejscach na polu Źródło: http://www.e-farmer.pl/ogolnie.php [dostęp 20.04.2017].

Chmura z danymi daje dużo więcej możliwości. Tworzy się wirtualna mapa przedsiębiorstwa. Nie trzeba wpisywać, co jest uprawiane na danym polu, bo siewnik ustawia się pod konkretne zboże z poziomu ciągnika. Za pomocą specjalnej aplikacji ciągniki z nadajnikami możemy śledzić w czasie rzeczywistym. Co więcej, śledzi je również serwisant. Po wystąpieniu usterki pracownik, nie zaglądając do maszyny, jest w stanie powiedzieć, co uległo awarii, czy można z tą usterką dalej pracować, jak długo trzeba będzie czekać na ewentualne sprowadzenie danej części, jaki będzie koszt naprawy i czy jesteśmy w stanie naprawić to 
sami. Podobne informacje może odczytać z maszyny również serwisant i zdalnie poinstruować (telefonicznie), co trzeba po kolei zrobić, aby pozbyć się usterki. Operatorom na bieżąco można wysyłać wskazówki i polecenia, które będą wyświetlane na ekranie.

\section{Optacalność}

Innowacja wiąże się z kosztami. Jest to inwestycja długofalowa, która z pewnością przyniesie zysk w odpowiednim czasie. Polskie rolnictwo cechuje się dużą liczbą małych gospodarstw, których areał podzielony jest na małe pola. W takim wypadku bardziej opłaca się przyjąć, że pole na całym jego obszarze jest jednakowo bogate w składniki mineralne, a badania spisać na papierze. Koszt zaimplementowania systemu jest niewspółmiernie duży do korzyści płynących z jego zastosowania, dlatego w Polsce ciągle tak niewielu rolników zdecydowało się na tego typu rozwiązania. W zachodniej Europie i USA taka praca staje się już powszechna. Warto również zastanowić się nad awaryjnością takich rozwiązań. Wiadomo, że komputery bywają zawodne. W maszynach rolniczych elektronika jest narażona na kontakt $\mathrm{z}$ kurzem, wodą, często pracy towarzyszą wstrząsy. Mimo niebezpieczeństwa powstania uszkodzeń mechanicznych główne usterki tych systemów związane są z oprogramowaniem. W przypadku firmy John Deere serwis próbuje podołać problemom. W ponad 70\% problemów pomagają aktualizacje. Komputer w ciągniku coraz częściej przypomina smartfon, więc aktualizacje nie wydają się niczym dziwnym.

\section{Logistyka}

Gospodarstwo rolne jest przedsiębiorstwem. W każdej firmie utrzymuje się jakieś zapasy. Tutaj są one specyficzne i zależnie od sezonu mogą być większe lub mniejsze. Zawsze jednak magazynuje się paliwo. Podczas „okien pogodowych” nie ma czasu tankować pojazdów na stacjach, bardzo często odległych. Przy pomocy wirtualnego kalendarza prac polowych ${ }^{12} \mathrm{i}$ zaplanowanych $\mathrm{w}$ nim zabiegów agrotechnicznych możemy łatwo przewidzieć, ile paliwa zużyjemy, a co za tym idzie, ile należy go zakupić, dzięki czemu koszty zapasu będą optymalne.

12 http://precyzyjnerolnictwo.com/zaczynamy/ [dostęp 20.04.2017]. 
Jeżeli ktoś przed erą Internetu zbierał rzetelnie zapisy wynikające $\mathrm{z}$ badań mikroskładników w glebie, wielkości plonów, wilgotności, musiał na to poświęcić dużo czasu. Aby uzyskać przejrzysty obraz danych, trzeba było przeznaczyć kolejne godziny na mapowanie zapotrzebowań itp. Dalej rozmowa z operatorem, od którego zależy efekt końcowy. Obecnie dane do chmury wprowadzane są automatycznie, tam przetwarzane, by następnie były widoczne dla wszystkich. Można odnieść wrażenie, że praca dzisiejszego rolnika przypomina pracę spedytora czy też pracownika do spraw zarządzania zapasami i zaopatrzeniem. Monitorując kalendarz oraz rynek, dokonuje on zakupów na podstawie map pól, statystyk z lat poprzednich i stanu magazynowego. Mając dokładnie wyliczone dawki, jest w stanie zakupić dokładnie tyle, ile potrzebuje, a mając pod ręką systemy rolnictwa precyzyjnego pokazujące informacje w stanie rzeczywistym, może dokonywać dostaw w myśl strategii Just in Time. Jest to szczególnie pomocne $\mathrm{w}$ przedsiębiorstwach $\mathrm{z}$ ograniczoną powierzchnią magazynową.

Transport w tej gałęzi gospodarki zmienia swoje znaczenie. Pola oddalone są coraz bardziej i w ujęciu logistycznym trzeba zastanowić się, czy opłaca się całą drogę przebyć traktorem. Przedsiębiorstwa coraz częściej posiadają w swoim parku maszynowym ciężarówki, które mogą przewozić plony lub dowozić maszyny na pole. Przewóz kombajnów, z powodu ich rozmiarów, praktycznie już niczym nie różni się od transportów ponadgabarytowych. Transport tego typu wykonuje się w nocy, najczęściej w konwojach przy eskorcie pilotów. Jest to duże wyzwanie w sytuacji kilku dni dobrej pogody, gdy uwaga całego przedsiębiorstwa zwrócona jest na osiąganie najlepszych efektów na polu (Kuziemska, Trębicka, Pieniak-Lendzion, 2016).

W rolnictwie pojawia się outsourcing. Nierzadko rolnicy korzystają z tego typu usług, ponieważ:

- nie mają odpowiedniego parku maszynowego,

- firmy wyposażone w odbiorniki GPS potrafią np. wyrównać pole w poziomie pod uprawy specjalne (zakup takich maszyn dla jednorazowego użycia jest nieopłacalny),

- przedsiębiorstwa korzystające z GPS wykonają prace dokładniej i szybciej.

Czas jest coraz częściej czynnikiem kluczowym. Optymalizacją procesów w ujęciu czasowym zajmuje się właśnie logistyka. Prawdopodobnie już niedługo systemy rolnictwa precyzyjnego będą same przygotowywać zamówienia na podstawie danych, które wprowadzono do systemu. Doprowadzi to do jeszcze większej oszczędności czasu.

Problematyczne było dawniej przewidywanie wielkości plonu, a co za tym idzie określenie potrzebnej powierzchni magazynowej. Czujniki w kombajnach już po kilku przejazdach pokazują, jak plonuje uprawa. Przy żniwach, które w dużych gospodarstwach trwają czasami ponad miesiąc, już na początku możemy określić, czy nasza powierzchnia magazynowa jest wystarczająca i już w tym momencie podjąć decyzję o ewentualnym wynajęciu dodatkowego miejsca. Daje to dużą przewagę nad gospodarstwami, które na koniec żniw (Kuboń, 2007) próbują wynająć magazyny, często za cenę dużo wyższą niż ta, która obowiązywała miesiąc wcześniej. 


\section{Podsumowanie}

Przy nieograniczonym budżecie wysoka produktywność nie jest niczym nadzwyczajnym. Niestety, takie warunki nie istnieją, dlatego też dzisiejszy świat dąży do podnoszenia produktywności przede wszystkim przez zastosowanie procesów optymalizacyjnych. Współczesne rolnictwo, działające pod presją czasu, czerpie $\mathrm{z}$ logistyki bardzo wiele. Rozwiązania od dawna sprawdzające się w przedsiębiorstwach produkcyjnych znajdują swoje odzwierciedlenie w gospodarstwach, obniżając koszty i skracając czas potrzebny na wykonanie określnych czynności, przy zachowaniu dbałości o dokładność. Rolnictwo jest sektorem gospodarki takim jak inne. W każdym sektorze gospodarki rozwija się logistyka, zatem również $\mathrm{w}$ rolnictwie pełni ona ważną funkcję.

\section{Bibliografia}

Barwicki J., Romaniuk W., (2012), Wykorzystanie zdalnych systemów rejestracji danych do kontroli pól uprawnych, „Problemy Inżynierii Rolniczej”, PIR (I-III), Instytut Technologiczno-Przyrodniczy w Falentach, Oddział w Warszawie, z. 1 (75), s. 15-24.

Dominik A., (2010), System rolnictwa precyzyjnego, Centrum Doradztwa Rolniczego w Brwinowie, Oddział w Radomiu.

Kokot W., Kolenda P., (2015), Czym jest Internet Rzeczy, Raport-Internet-Rzeczy-w-Polsce.pdf.

Kuboń M., (2007), Logistyka zaopatrzenia gospodarstw rolniczych o wielokierunkowym profilu produkcji, „Inżynieria Rolnicza”, nr 6 (94), Katedra Inżynierii Rolniczej i Informatyki, Akademia Rolnicza w Krakowie.

Kuziemska B., Trębicka J., Pieniak-Lendzion K., (2016), Logistyka transportu w rolnictwie, „Zeszyty Naukowe Uniwersytetu Przyrodniczo-Humanistycznego w Siedlcach", nr 109.

\section{Źródta internetowe}

http://encyklopedia.pwn.pl/haslo/rewolucja-przemyslowa;3967502.html [dostęp 20.04.2017]. http://encyklopedia.pwn.pl/haslo/rolnictwo;3968575.html [dostęp 20.04.2017].

http://precyzyjnerolnictwo.com/zaczynamy/ [dostęp 20.04.2017].

http://stat.gov.pl.

http://www.astor.com.pl/images/Industry_4-0_Przemysl_4-0/ASTOR_przemysl4_whitepaper. pdf [dostęp 20.04.2017].

http://www.controlengineering.pl/menu-gorne/artykul/article/czwarta-rewolucja-przemyslowa-

i-przemysl-40-co-oznaczaja-te-pojecia/part/1/ [dostęp 20.04.2017].

http://www.deere.pl/pl_PL/docs/html/brochures/publication.html?id=6e78fbad\#46 [dostęp

20.04.2017]. 
http://www.plattform-i40.de/140/Navigation/DE/Home/home.html [dostęp 20.04.2017].

http://www.ppr.pl/technika/maszyny/gps-w-rolnictwie-reflekcje-o-przyszlosci-rolnictwaprecyzyjnego-135653 [dostęp 20.04.2017].

http://www.snom.mb.tu-dortmund.de/cms/de/forschung/Arbeitsberichte/Design-Principles-for-Industrie-4_0-Scenarios.pdf [dostęp 20.04.2017].

http://www.vdi-nachrichten.com/Technik-Gesellschaft/Industrie-40-Mit-Internet-Dinge-Weg-4industriellen-Revolution [dostęp 20.04.2017].

https://www.agrofakt.pl/magistrala-isobus/ [dostęp 19.04.2017].

https://www.igipz.pan.pl/tl_files/igipz/ZGWiRL/ARP/03.Rozwoj\%20gospodarki\%20 rolnej\%20 w\%20Plsce.pdf [dostęp 20.04.2017]. 